\title{
Why are child poverty rates higher in Britain than in Germany? A longitudinal perspective
}

\author{
by \\ Stephen P. Jenkins (University of Essex, DIW Berlin, IZA Bonn, and CHILD Turin) \\ Christian Schluter (University of Bristol and CASE, LSE)
}

Revised draft, 12 February 2001

JEL classifications: I31, D31, I38, J13

\section{Acknowledgements}

Revised version of a paper presented at the Conference on Cross-National Comparative Research Using Panel Surveys, ISR, University of Michigan Ann Arbor, 26-7 October 2000, and at ISER (Essex) and CASE (LSE) seminars. Research funded by the Anglo-German Foundation. We also benefited from ISER's core funding from the UK Economic and Social Research Council and the University of Essex and CASE's core funding from the ESRC. For helpful comments and suggestions, we thank our conference discussant Dan Hamermesh, James Banks, Rich Burkhauser, Joachim Frick, John Hills, Dean Lillard, John Micklewright, Gert Wagner, and conference and seminar participants. The paper uses data from public-use BHPS and GSOEP files together with the 2001 edition of the Cross-National Equivalent File (http://www.data-archive.ac.uk; http://www.human.cornell.edu/pam/gsoep/gspindex.cfm). The Stata code used for data extraction and analysis is available from Jenkins on request.

\section{Correspondence}

S.P. Jenkins, Institute for Social and Economic Research, University of Essex, Colchester CO4 3SQ, UK. Email: stephenj@essex.ac.uk. Fax: +44 1206873151. 


\title{
Why are child poverty rates higher in Britain than in Germany? A longitudinal perspective
}

\begin{abstract}
We analyse why child poverty rates were much higher in Britain than in Western Germany during the 1990s, using a framework that focuses on poverty transition rates. Child poverty exit rates were significantly lower, and poverty entry rates significantly higher, in Britain. We decompose these cross-national differences into differences in the prevalence of 'trigger events' (changes from one year to the next in household composition, household labour market attachment, and labour earnings), and differences in the chances of making a poverty transition conditional on experiencing a trigger event. It is the latter which are most important in accounting for the cross-national differences in poverty exit and entry rates.
\end{abstract}




\section{Introduction}

Germany and the UK are the two largest and most economically successful nations in the European Union, but Germany does better in protecting children from low income. For example, according to the Statistical Office of the European Community, in 1993, 13 percent of German children lived in households with incomes below half the national average income, but in Britain the proportion was more than double this figure, 32 percent (Eurostat, 1997; the 12 country EU-average was 20 percent). The cross-national differences in child poverty rates have been reflected in differences in political interest in the topic in the two countries. The current UK government has pledged to halve the number of poor children within ten years and to eliminate child poverty altogether within 20 years (United Kingdom 1999). By contrast, children's poverty is much less of a political issue in Germany at present. In this paper we address the question of why child poverty rates differ between Britain and Germany using analysis of differences in rates of movement into and out of poverty, and decomposing differences in poverty transition rates into differences in the prevalence of 'trigger events' precipitating poverty transitions and differences in the chances of making a poverty transition conditional on experiencing a trigger event.

The distinctive contributions of our analytical approach are, first, its cross-national comparisons and, second, the focus on transition rates and their systematic decomposition. Although our application is to two specific countries and to children, the analytical framework is one that can also be straightforwardly used for comparisons between alternative sets of countries or to examinations of poverty trends within countries over time, and for other groups in the population. The first feature of our approach is motivated by the large cross-national differences in child poverty rates: they suggest that Britain has something to learn from Germany about how to protect children from low income. And arguably Britain's experience also provides cautionary lessons for Germany as pressure grows to increase labour market flexibility and to introduce reforms to the welfare state similar to those instituted in Britain over the last two decades. The lessons to be learned depend on how differences in German and British poverty patterns relate to differences in labour markets, marriage markets and welfare states. We shed light on these issues using the decompositions of transition rates - the second feature of our approach.

Why take a longitudinal perspective to explaining child poverty rates? If one uses a cross-section perspective, the natural temptation is to explain cross-national poverty 
differences in terms of differences in the prevalence of 'problem groups' such as lone parent families or workless households, etc., and differences in the risk of poverty for each group. This strategy is problematic because there are substantial movements into and out of problem groups between one year and the next - households form and split; people gain and lose jobs - so the policy target is a moving one. When constructing explanations of poverty patterns it is more natural to relate behaviour to transition probabilities rather than to the (state) probability of being poor, particularly since the factors which determine entry (or re-entry) to the ranks of the poor differ from the factors determining escape from poverty (as we show below). Recognising the relevance of the dynamic dimension to explanations of poverty also has implications for anti-poverty policy, changing its emphasis from supplementing incomes towards providing routes out of poverty and preventing falls into poverty (Ellwood 1998: 49, HM Treasury 1999: 5).

The relevance of a longitudinal perspective can also be seen from consideration of the identity summarising the evolution of the poverty rate: this year's child poverty rate $\left(h_{t}\right)$ is equal to last year's child poverty rate times the retention rate (one minus the exit rate, $x_{t}$ ), plus the entry rate $\left(e_{t}\right)$ times one minus the proportion of children not poor last year. If the poverty rate is constant at some steady-state level, then it equals the entry rate divided by the sum of the exit and entry rates:

$$
h_{t}=e_{t} /\left(e_{t}+x_{t}\right) \text {. }
$$

Thus cross-national differences in poverty rates depend only on cross-national differences in poverty entry and exit rates if there is no trend in poverty rates in either country.

The relevance of (1) as an organising principle for analysis is underscored by the fact that cross-sectional child poverty rates were stable during the 1990s in both Britain and (Western) Germany. This is demonstrated in Figure 1 which shows that the trends in child poverty rates for each country were flat, for both a relative and an absolute poverty standard. (More precise definitions are provided later.) The greatest deviations from the flat trend occurred in the mid-1990s in each country, but one should be cautious of reading too much into these variations, as they are within the bounds of sampling variation. A 95 percent confidence band for each annual poverty rate covers about 5 percentage points for Britain and slightly more in Western Germany.

$<$ Figure 1 near here $>$

We therefore rephrase the question in the title into one focusing on differences in poverty transition rates: why does Britain have a higher child poverty entry rate and lower 
child poverty exit rate than Western Germany? To pinpoint the sources of these differences in transition rates, the key idea that we employ is that

- household income changes between one year and the next, and poverty transitions in particular, are precipitated by 'trigger events' such as changes in household members' labour market attachment and earnings, or changes in their household composition; and

- these events have different impacts on the risk of a poverty transition.

It is these two dimensions that we isolate in our decompositions. We relate differences between Britain and Western Germany in child poverty transition rates to cross-national differences in probabilities of trigger events, and differences in probabilities of a poverty transition conditional on event occurrence. ${ }_{\text {The trigger events considered are: }}$

- changes in the number of workers in a child's household (working full-time and in total);

- changes in an child's household labour earnings, holding the number of workers fixed;

- movements into and out of a single-adult household; and

- changes in the number of household members, holding household type fixed.

We find that it is cross-national differences in the chances of making a poverty transition conditional on experiencing a trigger event, rather than differences in the prevalence of trigger events per se, which explain why child poverty exit rates in Britain are lower and poverty entry rates are higher than in Western Germany. The results point to the importance of the welfare-state-related differences as the principal source of Anglo-German differences in child poverty rates. In particular, relative to British children, German children are better protected against the consequences of adverse labour market events, and positive labour market events are reinforced to a greater extent.

The rest of the paper is structured as follows. In Section 2 we set out our analytical framework. We briefly discuss in Section 3 what existing evidence suggests are the main sources of Anglo-German differences in child poverty transition rates, considering differences in labour and marriage markets and the welfare state. In Section 4, we introduce our crossnationally comparable data sets, sub-files from the British Household Panel Survey and German Socio-Economic Panel, and explain key definitions such as the poverty line and trigger events. Child poverty transition rates for Britain and Western Germany in the 1990s are reported and discussed in Section 5. The decomposition and analysis of child poverty

\footnotetext{
${ }^{1}$ Other papers using the trigger event concept include Bane and Ellwood (1986), DiPrete and McManus (2000), Duncan (1993), Jenkins (2000), and Picot et al. (1999). Gottschalk and Danziger (2001) provide some decompositions of child poverty exit probabilities.
} 
transition rates follows in Sections 6 (poverty exits) and 7 (poverty entries). Section 8 provides concluding comments.

\section{A framework for examining cross-national differences in poverty transition rates}

To fix ideas, suppose that there is a set of mutually-exclusive events $j=1, \ldots, J$, which trigger exits from poverty. Then, among those children in a given country at risk of exit from poverty between one year and the next, the probability of exit is given by the sum of the probabilities for children that exit by each of the different events:

$$
\operatorname{pr}(\text { exit poverty })=\sum_{j=1}^{J} \operatorname{pr}(\text { exit poverty via event } j) .
$$

Each term on the right hand side can be written as the product of the probability of each event and the probability of exit conditional on event occurrence:

$$
\operatorname{pr}(\text { exit poverty })=\sum_{j=1}^{J} \operatorname{pr}(\text { exit poverty } \mid \text { event } j) \cdot \operatorname{pr}(\text { event } j) \text {. }
$$

By similar arguments, one can relate the probability that an at-risk child will enter poverty due to a set of mutually-exclusive trigger events $k=1, \ldots, K$, to the probabilities of each event and the probability of poverty entry conditional on event occurrence:

$$
\operatorname{pr}(\text { enter poverty })=\sum_{k=1}^{K} \operatorname{pr}(\text { enter poverty } \mid \text { event } k) \cdot \operatorname{pr}(\text { event } k)
$$

It follows that the cross-national differences in child poverty exit rates can be decomposed into a weighted sum of cross-national differences in event prevalence probabilities and cross-national differences in event-conditioned poverty transition probabilities:

$$
\Delta \operatorname{pr}(\text { exit poverty })=\sum_{j=1}^{J} \Delta \operatorname{pr}(\text { exit poverty } \mid \text { event } j) \cdot w_{j}+\sum_{j=1}^{J} \Delta \operatorname{pr}(\text { event } j) \cdot z_{j}
$$

where $\Delta$ is the cross-national difference operator, $w_{j}=\theta \cdot \operatorname{pr}(\text { event } j)_{\mathrm{WG}}+(1-\theta) \cdot \operatorname{pr}(\text { event } j)_{\mathrm{GB}}, z_{j}$ $=(1-\theta) \cdot \operatorname{pr}(\text { exit poverty|event } j)_{\mathrm{WG}}+\theta \cdot \operatorname{pr}(\text { exit poverty|event } j)_{\mathrm{GB}}$, and $0 \leq \theta \leq 1$. A similar expression can be derived for cross-national differences in poverty entry rates.

In our empirical application we focus our discussion on the various $\Delta$ terms per se, rather than provide exact numerical disaggregations using (5) and its poverty entry rate counterpart. There are three reasons for this. The first is that it is difficult to compile an 
exhaustive set of mutually-exclusive trigger events. A number of events may occur simultaneously and, although one could treat each joint occurrence as a separate event, there are practical limits to implementing this. An alternative might be to define a set of mutuallyexclusive events using a pre-defined hierarchy of event 'importance' (cf. Bane and Ellwood 1986), but the assumptions required are debatable. Our response to these issues is to focus on a subset of the most important events and to look at each of these one at a time, but also to examine an important joint event (changes in labour market attachment combined with household formation/dissolution). Second, and related, with this strategy we can also compare cross-national differences in probabilities that children are born poor - equation (3) only refers to the experience of existing children.

The third reason for focusing on decomposition components is that it is important to calculate these separately for different groups of children at risk of a poverty transition. (For example the outcomes and processes affecting exits from poverty by children in lone parent households differ from those for children in married couple households - (re)marriage is a potential route out of poverty for the former group but not the latter.) Aggregation of withingroup differences over at-risk subgroups would be possible in principle, but the value-added is relatively low. The strengths of our analytical approach derive from its transparent focus on the sources of the differences within each group.

The decompositions help to uncover the relative importance of the three key types of institution - labour market, marriage market, and welfare state - in explaining cross-national poverty differences. ${ }^{\square}$ The effects of differences in labour market or marriage market institutions (e.g. differences in the nature and extent of active labour market policies, or differences in matrimonial law) will be revealed most obviously through differences in the probabilities of the relevant trigger events. By contrast, differences in welfare states will be most obviously revealed by cross-national differences in income changes among those experiencing particular event. The primary goal of western welfare states is to directly modify the outcomes associated with various events using cash transfers (social assistance and social insurance benefits, and taxes).

\footnotetext{
${ }^{2}$ Arguably differences in the health of the national macro-economy are another potential source of poverty differences. Our prior, however, is that macroeconomic differences reveal themselves primarily through labour market differences (which we do examine).

${ }^{3}$ Of course the different incentive structures arising from a particular welfare state may also lead to differences in the likelihood of trigger events.
} 


\section{Anglo-German differences in child poverty transition rates: some priors}

Existing evidence provides mixed suggestions about why Britain has lower child poverty exit rates and higher child poverty entry rates than Germany does. The reasons are that some factors offset each other, the sources of the stylised facts are diverse, and the information does not necessarily refer to families with children.

\section{Differences in the prevalence of labour market and demographic trigger events}

Consider first the relative prevalence of labour market and demographic trigger events. Britain is typically cited as having a more 'flexible' labour market than Germany, and greater turnover between employment and unemployment. See for example Nickell (1997). On this basis one might expect that earnings mobility among persons not changing jobs to be greater in Britain than Germany, but this may not be so: it is now well-established that Germany has higher earnings mobility than the USA (Burkhauser et al., 1998; Schluter and Trede, 1999). One expects higher rates of both job loss and job gain in Britain than Germany, but this has ambiguous implications for poverty. Higher risks of job loss lead to higher poverty entry rates, other things equal, but higher risks of job gain lead to higher poverty exit rates.

A similar argument applies to marriage market events - again existing evidence suggests that turnover is higher in Britain. But higher risks of divorce and separation are consistent with a higher child poverty entry rate, whereas a higher marriage risk is consistent with a higher child poverty exit rate. Fertility rates are lower in Germany than in Britain (Eurostat, 2000), a factor contributing to a smaller proportion of children born into poverty.

\section{Differences in financial consequences for those experiencing trigger events}

The expected Anglo-German contrast is more clear cut if one considers the financial consequences associated with trigger events, but here too there are factors that complicate conclusions. The standard view is that the German welfare state provides a better financial cushion against adverse events such as job loss than the British welfare state (at least over the

\footnotetext{
${ }^{4}$ The number of legal marriages per 1000 people in 1995 was 5.3 in Germany (East and West) but 5.5 in the UK, and the number of divorces per 1000 people were 2.1 and 2.9 respectively (Eurostat, 2000).
} 
short-term). For instance Germany provides earnings-related unemployment insurance and unemployment assistance whereas in the UK unemployment insurance is flat-rate.

Estimated income replacement rates vary, depending on assumptions about, for instance, household composition, work record and earnings levels. The OECD recently calculated that in 1997 an unemployed married couple with two children would receive, if on unemployment insurance, a net income out of work that was 73 percent of net income at work (assuming average earnings), whereas the replacement rate for the corresponding UK family would be 64 percent (OECD, 1999). Ditch et al. (1996: 74) estimate the net replacement rate in 1995 for a couple at half average earnings with one child aged two to be 93 percent in Germany and 62 percent in the UK. For a couple with two children, the corresponding ratios were 101 percent and 69 percent.

Just as a high replacement ratio may be taken as evidence that one country provides a better cushion against adverse events such as unemployment, a high ratio also suggests that the financial returns to the average unemployed person from taking a job are lower. If this disincentive effect is sufficiently effective, then the only people who take jobs will be those with sufficiently high financial gains from taking a job. In this case the probability of moving out of poverty conditional on taking on more work is likely to be higher in the high replacement ratio country (Germany rather than Britain in this case).

Large negative income changes associated with divorce and separation have been documented for a range of countries. Burkhauser et al. $(1990,1991)$ drew attention to similar impacts in Germany and the USA, and Jarvis and Jenkins (1997) reported findings for Britain that were in the same range. The most plausible explanation for cross-national similarities is that gender inequalities in the labour market and home that are common across countries are more important than differences in structure and coverage of the welfare state (see Holden and Smock 1991 for elaboration). Whether the positive income effects associated with (re)partnering by a lone mother are larger in Germany or Britain is also not clear. On the one hand, the German tax system provides strong financial rewards to marriage especially through its income-splitting rules (the UK has independent taxation of men and women). On the other hand, these rewards also provide an incentive for a married woman not to work. If (re)partnering is with someone with low labour attachment (and who remains so), then the reduction in the risk of poverty associated with (re)partnering may be relatively low.

In sum, the most clear cut hypotheses about Anglo-German differences are: 
- the probability of job gain, and the associated conditional probability of exiting poverty, are each higher in Britain than Germany (having offsetting impacts on differences in the overall poverty exit rate).

- the probability of job loss, and the associated conditional probability of entering poverty, are each higher in Britain than Germany (having reinforcing impacts on differences in the overall poverty exit rate).

- the probability of household formation is higher in Britain than Germany (contributing to a higher poverty exit rate), but

- the probability of household dissolution is also higher in Britain (contributing to a lower poverty exit rate).

The evidence concerning Anglo-German differences in the conditional probabilities of poverty transition associated with demographic changes is less clear cut. Overall, the fact that there are many factors potentially at work, some of which may offset others, underlines the need for a systematic disaggregated analysis.

\section{Data and definitions}

\section{The BHPS and GSOEP, and sample numbers}

We use eight waves of data, survey years 1991-8, of the British Household Panel Survey (BHPS) and the German Socio-Economic Panel (GSOEP). Both surveys are of similar design. The first wave of each survey (1991 for the BHPS, 1984 for the GSOEP) was a nationally representative sample of the population living in private households, in the German case also including an over-sample of 'guest workers' (foreign-born residents and their children) recruited abroad during the economic booms of the 1960s. Original sample respondents have been followed and they (and co-resident adults) have been interviewed at approximately one year intervals subsequently. Children in original sample households have also been interviewed in their own right when they became adults. We use survey weights in our analysis in order to account for differential non-response and attrition (and the differential sampling probabilities of GSOEP guest worker sample members).

We focus on the period 1991-8 because the BHPS does not cover the 1980s as the GSOEP does. Our German sample for each year consists of the adults and children residing in 
the Länder (provinces) that comprised the former West Germany, 'Western Germany' for short. ${ }^{1}$ We do not consider those living in the former East Germany: the huge changes in the region's economy and institutions over the 1990s after re-unification would muddy the crossnational comparison with Britain. In any case, we calculate that child poverty rates in eastern Germany fell significantly over this period, whereas they changed relatively little in both Britain and Western Germany (Figure 1).

Our analysis sub-samples consist of those individuals in households with non-missing data on income and household composition. For Britain there is information over the eight waves for some 18,731 different individuals of whom some 4,819 are children - defined by us to be those individuals aged under 17 years - resulting in 99,876 person-year observations (23,169 for children, 76,707 for adults). For Western Germany, there is information for some 16,450 individuals $(4,494$ children), resulting in 95,023 person-year observations $(20,988$ for children, 74,035 for adults). We have unbalanced panels for each country. Only about one third of all the children ever present in each panel were present in all eight waves, the main reason being that a significant number of them were born after 1991. Taking each crosssection of data separately there are approximately 2,500 children in Western Germany and approximately 2,800 in Britain. Although these are relatively large samples when all children are considered together, the numbers in some subgroups (notably lone parent and 'other' households - defined below) are quite small in any given year: some 200-300 children or fewer (with the number of households smaller still). Hence most analysis of subgroups is based on data pooled from all eight waves. Two factors reduce sample sizes a little further in some calculations (and are reflected in larger standard errors). First, variables summarising the total number of workers in a household (defined below) have missing values for households in which there was at least one adult that did not provide an interview. ${ }_{\text {Second, in our analyses }}$ of poverty entries and exits we restrict analysis to those individuals who were children at two consecutive waves (before and after the relevant transition).

\footnotetext{
${ }^{5}$ More specifically, we use persons from GSOEP samples A-D if they satisfy the condition about current residence. We do not use new supplementary sample E (the 1998 Ergänzung sample).

${ }^{6}$ The household income data includes imputed values, so there are non-missing values as long as not all adults were non-respondents.
} 
We count an individual as being poor if the needs-adjusted real net annual income of the household to which he or she belongs -'income' for short - is less than the poverty line. Household net income is the sum across all household members of cash income from all sources (income from employment and self-employment, investments and savings, private and occupational pensions, and other market income, plus cash social security and social assistance receipts), minus direct taxes. The needs adjustment is done using an equivalence scale according to which each household income was deflated by a

household equivalence factor $=[$ (number of adults $)+\alpha^{*}($ number of children $\left.)\right]^{\beta}$,

$$
\text { where } \alpha=0.7, \beta=0.75 \text {. }
$$

This scale is the one of the two-parameter ones recommended by the US National Research Council Panel on Poverty and Family Assistance (Citro and Michael, 1995). In order to consider the sensitivity of results to changes in the equivalence scale, we repeated our analyses using three other scales: $(\alpha, \beta)=(0.7,0.5),(0.5,0.75),(0.5,0.5){ }^{\square}$ The effects of changing the scale were minor and so are not discussed. (See Appendix A for details.) Incomes were deflated to 1998 prices using a national price index (source: IMF Financial Statistics). Household income measures are based on variables available in the 2001 edition of the Cross-National Equivalent File, a derived variable subfile of comparable cross-national data from the GSOEP and the BHPS (and the US PSID and Canadian SLID): see Burkhauser et al. (2000) and Bardasi et al (1999) for further details.

The poverty line we use in most of the analysis is 60 percent of contemporary national median income, a threshold recommended by the Eurostat Task Force (1998) for crossnational poverty comparisons. For Britain, this corresponds to a 1991 poverty line of $£ 4,665$ per annum, slightly higher cut-offs in each successive year, with a 1998 poverty line of $£ 5,166$, some 11 percent higher than the 1991 one. These changes reflect the economic growth over the decade as the economy came out of recession after 1991. Germany's recession came later, starting around 1992-3, with recovery not until the end of the period that we consider. As a result, median income, and hence the poverty line we use, followed a relatively flat trend over time. The poverty lines are DM 15,195 for survey year 1991 and DM

\footnotetext{
${ }^{7}$ See Jenkins and Cowell (1994) for analysis of the sensitivity of poverty and inequality indices to changes in $\alpha$ and $\beta$. They show that the scale with $(\alpha, \beta)=(0.5,0.75)$ corresponds to the semi-official British equivalence scale (the so-called 'McClements before housing costs' one).
} 
15,008 for 1998 (about 1 percent lower than the 1991 level), varying in between by at most 5 percent.

Our use of a poverty line that varies in value according to the distribution being considered - a 'relative' poverty line by contrast with an 'absolute' poverty line which is fixed in real terms across years and countries - is potentially controversial. Measures of relative poverty are sensitive to differences in inequality as well as the incidence of low income per se (and relative poverty rates may rise even if all incomes have risen). But this is a property of relative measures, rather than a fundamental criticism. Relative poverty lines of the type that we employ are widely accepted in Europe. It is a specification reflecting the

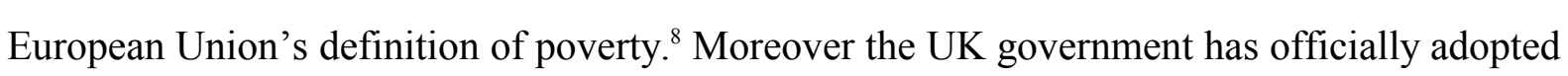
this relative poverty definition for monitoring progress towards its goal of eradicating child poverty (United Kingdom, 1999). The report of the US Research Council Panel on Poverty and Family Assistance also suggested that the US official poverty line should be updated in line with secular income growth (Citro and Michael, 1995).

We repeated all our analysis using an absolute poverty line set equal to 60 percent of the 1991 British median income $(£ 4,665$, or DM 15,355 when converted at the 1991 OECD purchasing power parity). Our results changed little. The reason is that, over the 1990s, not only was secular growth in median income relatively small, but also the shape of the income distribution changed hardly at all, in both countries.

For both fraction-of-median-based absolute and relative poverty lines, child poverty rates are higher in Britain than Germany - i.e. the poverty line corresponds to a higher percentile of the income distribution in Britain than Germany. One might therefore argue in this case that the nature of the population at risk of a poverty transition is rather different in each country, thereby introducing non-comparability into the analysis. To address this concern we also repeated our analysis using a low-income threshold equal to the twentieth percentile of the all-persons income distribution in each country in each year, thus ensuring that exactly 20 percent of persons were poor. The effect was to narrow estimated crossnational differentials in many decomposition estimates, but the general tenor of our conclusions was not altered. (See Appendix B for details.)

\footnotetext{
${ }^{8}$ The EU Council of Ministers defined people to be poor if their 'resources (material, cutural, and social) are so limited as to exclude them from the minimum acceptable way of life in the Member State in which they live' (Council Decision, 19 December 1984, quoted by Atkinson 1998: 2). A 'half national average income' poverty line has been the concrete implementation of this definition in a large number of official Eurostat and other studies. See Atkinson (1998) for extensive discussion of European poverty lines, and official poverty lines in
} 
Given a definition of the poverty line, we define a poverty entry as a change in income from being above the line in one year to below the line in the subsequent year. A poverty exit is a change in income from below the line to above the line. Arguably these definitions are over-sensitive to small changes in income for individuals close to the poverty line, and may pick up 'non-genuine' poverty transitions. To check the robustness of our results, we redefined poverty exits as an income increase from below the poverty line to at least 10 percent above the poverty line, and a poverty entry as an income fall from above the poverty line to at least 10 percent below the poverty line. The change in definition reduced the estimated magnitude of each poverty transition statistic, for both countries, but did not change the cross-national pattern of differences and thence our conclusions. (See Appendix B for details.)

The definition of demographic and labour market variables, and trigger events

We classified children in several ways according to the type of household they lived in and by household labour market attachment. Changes in classifications between one year and the next were used to define trigger events.

We defined a 'lone parent household' to be a household containing one adult plus one or more children. A 'married couple household' is a household containing two or more adults with or without children, where the spouse of the head of household is present. ('Married' refers to both legal marriages and cohabiting unions.) Some 15 percent of British children and 9 percent of Western German children live in lone parent households (pooled data for 19918). About 80 percent of all children lived in married couple households in Britain and 90 percent in Western Germany. The remaining group of 'other' households comprised two or more adults living together with or without children and where the household head has no spouse present. Included under this heading may have been a lone parent and her children sharing the household with unrelated adults (for example another lone parent family) or the lone parent's own parents. Thus our 'lone parent household' group does not include all lone parents and their children. On the other hand, the fraction of all children in the 'other' group is small: 4 percent in Britain, 2 percent in Western Germany.

general. 
We defined an adult household member to be a 'worker' if his or her annual labour earnings were positive, and he or she worked at least 52 hours over the reference year (defined below). Full-time workers were those who worked 1,500 or more hours per annum. For each child we calculated the number of workers and the number of full-time workers in his or her household.

Trigger events were identified from year-on-year changes in demographic and labour market characteristics of each child's household. For example, 'demographic' events include a change in household size (conditioning on no change in household type), and entry to and departure from a lone parent household. 'Labour market' events include a change in the number of workers (full-time and in total), and a change in real (unequivalised) household labour earnings of at least 20 percent conditioned on there being no change in the total number of workers in the household. ${ }^{\text {g }}$ Our aim was to distinguish between job gains and losses and 'pure' earnings changes, where the latter are driven primarily by changes in the annual work hours of household members that did not involve job change(s). The threshold of 20 percent was chosen to ensure that transitory earnings variations were not counted as events. Each event is considered independently, one at a time, though we also consider some jointly occurring events.

The reference periods for income, household characteristics, and trigger events

Age, sex, and thence household type and composition, are variables measured at the date of interview in each survey year, i.e. typically in the Autumn for BHPS respondents (October is the modal interview month) and in the Spring for GSOEP respondents (March is the modal interview month). The reference period over which annual household income (and labour earnings) are calculated is, for the BHPS, the 12 months up to the $1^{\text {st }}$ of September of the survey year (e.g. from 01.09.96 to 31.08 .97 for survey year 1997) and, for the GSOEP, the reference period is the calendar year prior to the survey year. In both surveys, household incomes are derived by aggregating the incomes of all the household members present at the time of the interview (incomes of members who left during the year are not counted).

\footnotetext{
${ }^{9}$ The distinction between 'demographic' and 'labour market' events should not be pushed too far. Since our labour market measures are defined at the level of the household (to match the definition of income), changes in household composition may also effect the number of workers.
} 
There is therefore a potential mismatch in timing between demographic events over the year $t-1$ to $t$ and changes in annual income. In particular the reference period for annual income for households surveyed in year $t$ partially overlaps the survey date at year $t-1$. As a result, authors such as Burkhauser et al. (1986), Burkhauser et al. (1990, 1991), and DiPrete and McManus (2000), have taken events measured between interviews at $t-1$ and $t$ and compared them with annual household incomes at years $t-1$ and $t+1$. The problem with this convention is that calculations of incomes at $t+1$ may be based on a different set of individuals than those present at $t$ - there is substantial flux in household membership over time. Hence the income change calculation may reflect this subsequent change rather than the trigger event of interest. - Observe too that trigger events relating to arrivals and departures of household members already have some impact on year $t$ income, because household incomes are calculated only for the individuals forming the household at the year $t$ interview.

In our view, therefore, the appropriate choice of observation window width for income changes is not clear cut (and may depend on the particular event under consideration). In order to check the robustness of results, we considered income changes both between years $t-$ 1 and $t$, and between years $t-1$ and $t+1$. The largest differences between corresponding statistics are likely to arise in the changes in poverty risks estimated to be associated with significant changes in household composition, as with a household split forming a lone parent household. In this case, the very immediate income change - typically precipitate - is likely to differ from the net change in circumstances over even a slightly longer period (during which eligibility for government transfers or child support is established). By contrast changes in income between $t$ and $t-1$ are better matched with the changes between $t$ and $t-1$ in household labour earnings or the number of workers in the household - these variables have the same reference period, by construction.

\footnotetext{
${ }^{10}$ This potential mismatch problem is endemic in panel comparisons based on annual income measures. An alternative would be to use current income measures (income round about the time of the interview) as there would then be a close correspondence between the income reference period and household composition. Current income measures are not available for the full 1991-8 period for the GSOEP.

${ }^{11}$ Of course these adjustments (and subsequent ones) and their associated income outcomes are of also of interest, but that is a separate issue from the one addressed here - which concerns the income change associated with a given trigger event. Whatever the case, income changes between $t-1$ and $t$ or between $t-1$ and $t+1$ are short-term changes rather than longer-term ones. Cf. DiPrete and McManus who also consider cross-national differences in 'the rate of subsequent events that cause the original effect to intensify or decay' (2000: 3 ) in their US-Germany comparison of income mobility. They used observation window widths of two, three, five and seven years.
} 


\section{Anglo-German differences in child poverty transition rates}

Before proceeding to the decomposition analysis, we summarise the cross-national differences in annual poverty exit and entry rates for children that are to be examined. The poverty line is 60 percent of contemporary national median income. Table 1 displays the transition rates broken down by child's household type in the year prior to the potential transition. 2 Also shown are the pooled cross-sectional poverty rates for each group (cf. Figure $1)$.

The estimates in the first row of Table 1, for all children, are the basis of our earlier claim that child poverty exit rates are lower and child poverty entry rates are higher in Britain than in Western Germany. (Both differences are statistically significant at the 95 percent level.) The difference in exit rates ( 25 percent compared to 36 percent) is much larger in absolute terms than the difference in entry rates ( 11 percent compared to 7 percent), but in proportionate terms the differentials is larger for the entry rate (and more than four-tenths in both cases).

\section{$<$ Table 1 near here $>$}

The all-children differentials in transition rates are echoed when one considers children in each of the three household type subgroups separately (though observe that the differences in entry rates have large confidence intervals). At the same time there are some cross-national similarities. For example, in both Britain and Western Germany, children from lone parent households have below (national) average poverty exit rates and above average poverty entry rates. Children from married couple households in both countries below average poverty entry rates (poverty exit rates are about average).

\footnotetext{
${ }^{12}$ All estimates of standard errors of probabilities and rates account for the clustering that arises when there are repeated observations per household in each wave. We took no account of the complex survey design in the BHPS and GSOEP (but information is not available to do this in the same way for both surveys), nor did we account for repeated observations on the same person across waves (in the pooled analyses). For this reason, our estimates may be under-estimates. Also we did not account for the sampling error associated with the poverty line itself. However Preston (1995) shows that this may lead to under- or over-estimates of the true standard error for the poverty rate. His simulations indicate that ignoring the endogeneity of the relative poverty line will be of little practical consequence in our case.
} 


\section{Trigger events and movements out of child poverty}

We analyse exits from poverty by children in lone parent households separately from those by children in married couple households. The 'demographic' trigger events considered are a fall in the child's household size - this corresponds, for example, to an older sibling becoming non-dependent or leaving home - plus, for the former group, leaving a lone parent household (for example by (re)marriage of the custodial parent). The other trigger events analysed are labour market ones: an increase in the number of workers, full-time workers in particular, and increases in labour earnings with no change in the number of workers.

\section{Exits from poverty by poor children in lone parent households}

The estimates for poor children from lone parent households are shown in Table 2. The first row of the table shows the exit rates for this group as a whole over a one year interval $(t-1$ to $t$ ) - as shown earlier in Table 1 - whereas the second row shows the exit rate for the period $t$ 1 to $t+1$.). With a longer observation window exit rates are slightly higher in both countries, but the cross-national differential persists. The remaining rows of Table 2 report the estimates of the two types of statistics for five trigger events: $\operatorname{pr}($ event) defined over the period $t-1$ to $t$, and $\operatorname{pr}$ (poverty exit|event) for each of the two observation periods. Decreases in household size are very rare, so we do not consider this event further.

We look first at the cross-national differences in the probability of trigger events. Table 2 shows that the chances of moving out of a lone parent household over a one year interval are larger in Britain than Western Germany (17 percent compared to 13 percent). The cross-national relativity is reversed, however, for the chances of gaining a full-time worker. In Britain the probability is about 0.09 but almost 0.15 in Western Germany. ${ }^{1 .}$ On the other hand, the probability of the joint occurrence of these two events is much the same in the two countries, 5-6 percent. Put another way, of those children with gains in the number of fulltime workers, in Britain the majority also moved out of a lone parent household, whereas a minority did in Western Germany. The most striking cross-national difference in trigger event occurrence is in the prevalence of an increase in real household labour earnings, experienced

13 Here, and throughout the table, some caution is required in drawing conclusions about the statistical significance of the differences: e.g. for each of the two events cited so far, the asymptotic ' $t$ '-ratio for the crossnational difference is less than two. Standard errors for the German estimates are relatively large (note the 
by almost two-thirds of British children, but only about one half of Western German children. Both estimates are much larger than the probability of increases in the number of full-time workers. Thus it appears that, in both countries, increases in annual work hours (for alreadyworking households) are more common among poor lone parent households than are moves into full-time work.

When we consider the probabilities of exit from poverty conditional on having experienced a trigger event, we find that cross-national differences are relatively small for departures from lone parenthood, though the estimates themselves are quite high in each country: just under one half. When the observation period is extended a further year, a crossnational differential appears, with the conditional poverty exit rate becoming markedly higher for Western Germany than Britain.

The size of these effects is, however, dwarfed by the reductions in poverty risk that are associated with an increase in the number of full-time workers: the conditional exit probability in this case is some 74 percent in Britain and even higher in Western Germany, 82 percent. Extension of the observation period moderates these estimates somewhat, to a probability of around two-thirds in both countries. Experience of both events increases the conditional poverty exit rates, as expected, though by less in Britain than Western Germany. By contrast, increases in household labour earnings have a much smaller association with poverty exits, particularly in Britain. About one third of the German children experiencing this event left poverty over the same period (almost one half if we look a year later), compared to only 11 percent of British children (or 17 percent a year later).

$<$ Table 2 near here $>$

Assembling the evidence from the decompositions, we conclude that there are several related reasons why poverty exit rates for children in poor lone parent households are higher in Western Germany than Britain. In Germany the likelihood of a move into full-time work is higher, and when this does occur, it has a greater poverty reduction impact than in Britain. Increases in labour earnings due to increases in work hours among already-working households are relatively common in both countries (though more so in Britain than in Germany), but the associated poverty reduction is somewhat smaller in Britain. Thus the cross-national difference in child poverty exit rates appears to be explained more by the differences in what happens to income conditional on more work, rather than more work per

relatively small sample size). 
se. Other factors such as the rate of departure from lone parenthood (higher in Britain) or the positive financial consequences of re-partnering - about the same in both countries - are less important.

This in turn suggests the key importance of the German tax and benefit system for reinforcing the income impact of more work - whether through longer hours for alreadyworking parents, or by taking up a job. In this light, the results suggest that recent British active labour market policies such as the New Deal for Lone Parents, intended to increase employment rates, will indeed have an anti-poverty effect, particularly if they increase the proportion of lone parents working full-time, but these policies will be significantly reinforced if the rewards from working are also increased. Thus other recent British policy initiatives in the late 1990s that raised the benefits paid to parents working full-time (first via Family Credit and, since October 1999, the Working Families Tax Credit) are measures likely to reduce the cross-national differential in child poverty exit rates in future. The national minimum wage, introduced in October 1999, is likely to make a positive contribution as well but, given the relatively low rate at which it was set, the in-work benefit initiatives are likely to have a larger impact. ${ }^{4}$

\section{Exits from poverty by poor children in married couple households}

Anglo-German differences in poverty exit rates for poor children in married couple households are large: around 27 percent in Britain compared with about 36 percent in Western Germany. This differential remains if the observation period is extended a further year (the exit rates are then 36 percent and 42 percent respectively). See Table 3 which also displays probabilities broken down by types of trigger event.

Decreases in household size are again so rare that they can play virtually no role in explaining the cross-national poverty exit rate differential. The fraction of children in households with an increase in the number of workers is one third higher in Britain than in Western Germany (20 percent compared with 15 percent). There is an even larger differential in the prevalence of increases in the number of full-time workers: the rate in Britain is 15 percent, whereas it is one in ten in Western Germany, fifty percent smaller. Much more common in both countries are increases in household labour earnings among already-working

\footnotetext{
${ }^{14}$ See Piachaud and Sutherland (2000).
} 
households and, as for poor lone parent households (Table 2), the proportion is higher in Britain than in Western Germany, 41 percent compared with 32 percent. Other things equal, these differences would lead to higher poverty exit for Britain which of course is not the actual case. Working in the opposite direction are the cross-national differences in the financial consequences of the trigger events.

Among Western German children with an increase in the number of household members working, one half also exit poverty, but among British children experiencing the same event, the fraction is only 40 percent. The cross-national differential is similar when children with an increase in the number of full-time workers are considered. Some 57 percent of Western German children in this group also leave poverty, but only 50 percent of British children. As the observation window is extended one year further, these differentials increase: the British estimates remain much the same but the proportion of non-poor German children increases. The cross-national difference in the reduction in poverty rates associated with an increase in household labour earnings among already-working households is particularly striking. Almost two-thirds of German children experiencing this event leave poverty after a year (63 percent), but less than one third of British children (28 percent). Another year later the cross-national differential is smaller but still large (the proportions non-poor are 57 percent and 36 percent respectively).

$<$ Table 3 near here $>$

Overall, the estimates shown in Table 3 suggest that, as was the case for children in lone parent households, Anglo-German differences in child poverty arise from differences in the financial consequences associated with events rather than differences in event prevalence. Indeed, by themselves the latter would imply higher exit rates in Britain. The potential importance of policies recently introduced in Britain, such as the Working Families Tax Credit - available to all low-income working parents, not only lone parents - is again underlined.

\section{Trigger events and movements into child poverty}

We now turn to consider entries to poverty. We only analyse what happens to non-poor children from married couple households as sample numbers for non-poor children in other household types are small. The estimates are reported in Table 4. The first row shows that 
poverty entry rates among all children in the at-risk group are higher in Britain than Western Germany (10 percent compared with 6 percent) and this differential is slightly larger still if a two-year interval is used (12 per cent compared with 6 percent).

To what extent can cross-national differences in trigger event prevalence account for these differences? The probability of a decrease in household size (but no change in household type) - arising e.g. via birth of an additional sibling - is about one-twentieth in both countries. The chances of joining a lone parent household are very slightly higher in Britain than in Western Germany, but the probability is small in both cases (3 percent compared with 2 percent), so this factor cannot be responsible for the difference in poverty entry rates. Moreover the incidence of falls in household labour earnings (e.g. because of working hours reductions that do not involve job loss itself) is the same in both countries, 8 percent. But what does play a marked role are differences in job loss rates. In Britain almost one fifth (18 percent) of children experienced a decrease in the number of workers, and about the same proportion a decrease in the number of full-time workers (17 percent). These estimates are roughly twice the corresponding fractions for Western Germany, 9 percent and 8 percent respectively.

\section{$<$ Table 4 near here $>$}

Turning now to the poverty outcomes for children experiencing the various trigger events, we see that the choice of the observation period for income change now makes a noticeable difference to the conclusions that might be drawn (compared to the exit rate decompositions). For both countries, extension of the interval from one year to two leads to a reduction in the proportion entering poverty and for all the trigger events (with the exception of increases in household size, and newborn children - discussed below). Although the conditional poverty entry rate associated with each trigger event is broadly similar in the two countries, the fall in entry rate with lengthening the observation period is greater for Germany, thereby revealing a cross-national differential in entry rates after two years.

Among children moving into a lone parent household between the interviews in years $t-1$ and $t$, for example, about 60 percent of children enter poverty between income years $t-1$ and $t$, in both countries. But the poverty entry rate for the interval $t-1$ to $t+1$ is about 48 percent for British children, twice the corresponding entry rate for German children (24 percent). It seems that there is a sharp short-term reduction in income associated with family dissolution in both countries, but after a period of adjustment in which circumstances improve, the net effect is that greater protection against poverty is provided to German 
children relative to British children. A similar pattern arises with the loss of one or more workers from the household (whether full-time or not), though the poverty risks involved are somewhat smaller. Approximately one fifth of children enter poverty in the short-run in both countries, but if the two-year observation window is used, the entry rate is around 13 percent in Western Germany but still one fifth in Britain. As expected, the interval-length effect is more muted for the estimates of poverty entry rates for children who experience decreases in household labour earnings, but it remains the case that protection against joining the ranks of 'working poor' households is less in Britain than in Western Germany.

The last two rows of Table 4 provide information about the contributions to the child poverty rate by children born into already poor households. (All the calculations reported so far were based on samples of children already present in the household at year $t-1$.) It appears that the proportion of households with a newborn child in an average year is rather higher in Britain than in Western Germany: just over 4 percent compared to just 1 percent. This is, however, an over-estimate of the true differential arising from the way these children are identified in the surveys. In addition the proportion of newborn children that were born into poor households is much the same in both countries, about one quarter. Both sets of statistics suggest that differences in fertility and the experiences of newborn children contribute little to Anglo-German differences in child poverty rates.

Overall, the picture for child poverty entries is not symmetric to that of poverty exits. In particular the greater prevalence of trigger events in Britain relative to Western Germany (for most events) now contributes to the cross-national differential in the poverty transition rate rather than offsetting it. The other main difference from the exit rate analysis is that the largest conditional poverty entry rate is for the trigger event 'joining a lone parent household', whereas the largest conditional poverty exit rate is associated with increases in the number of full-time workers. These results are consistent with earlier research about the population as a whole for the USA (Bane and Ellwood 1986) and Britain (Jenkins 2000) showing that the impact of 'demographic' events was greater for poverty entries than for poverty exits.

What the entry rate decomposition analysis shares with the exit rate analysis, though, is the finding of the Anglo-German differential in the financial changes associated with given events, and this suggests once more the important role of the German welfare state. The

\footnotetext{
${ }^{15}$ Newborn children are those aged zero in year $t$. Age in the GSOEP is calculated as survey year minus birth year (birth month data is not available, as it is in the BHPS). But GSOEP interviews are typically occur in March each year, and BHPS interviews in October, so the chances of observing a newborn child (as defined) are lower
} 
German tax and benefit system provides better protection to children's incomes against adverse events than the British system does, not just better reinforcement of positive events. This is unsurprising given greater role played by social insurance rather than means-tested social assistance in the German welfare state. ${ }^{16}$ The greater demographic and labour market turnover in Britain brings these effects more into play in the context of poverty entries intensifying the effects of welfare state differences - rather than offsetting them as for exits. Recent British active labour market initiatives have concentrated on increasing movements from unemployment into work and making work pay (see earlier). Our results for poverty entries highlight a potential payoff to policies in Britain that prevent job loss and promote job retention rates for those individuals who already have or get a job.

\section{Concluding comments}

Our aim has been to provide a longitudinal perspective on why child poverty rates are higher in Britain than in Western Germany. We argued that it was important to rephrase the question in terms of poverty transition rates: why are child poverty exit rates lower, and child poverty entry rates higher, in Britain than in Western Germany? To address these issues we have used a form of decomposition analysis, comparing cross-nationally the prevalence of events that trigger poverty (changes in household composition and household labour market attachment or earnings) and the chances of making a poverty transition conditional on experiencing a trigger event. It turns out that is the latter type of difference that is the most important, for both poverty exits and poverty entries. Consistent with the arguments rehearsed in Section 2, these findings reflect differences between the German and British welfare states, in particular the German one providing a greater cushion against adverse events and better reinforcement of positive events. Differences in the prevalence rates of trigger events do, of course, also play a role; a notable example being the greater risk of job loss in Britain compared to Western Germany.

\footnotetext{
in the GSOEP than in the BHPS.

${ }^{16}$ But the greater role of social insurance cannot be the full story. As DiPrete and McManus (2000) and others have pointed out, eligibility among lone parents is relatively low: means-tested social assistance is particularly important for this group (as in Britain). Generosity of payments aside, greater income protection for children in households that split in Germany also comes from larger child support payments from the non-coresident parent.
} 
These conclusions are robust to adjustments for errors in measurement of poverty transitions, and changes in the definition of the poverty line and in the equivalence scale used to adjust income for differences in needs. We have also raised questions about the appropriate reference period over which to measure the income changes associated with trigger events, an issue that has received insufficient attention in previous work. As it happens, the choice does affect some estimates (notably those for lone parent households), but the patterns of AngloGerman differentials remain robust.

\section{References}

Atkinson, A.B. (1998), Poverty in Europe, Blackwell Publishers, Oxford.

Bane, M.J. and Ellwood, D.T. (1986), 'Slipping into and out of poverty: the dynamics of spells', Journal of Human Resources, 21, 1-23.

Bardasi, E., Jenkins, S.P., and Rigg, J.A. (1999), 'Documentation for derived current and annual net household income variables, BHPS Waves 1-7', Working Paper 99-25, Institute for Social and Economic Research, Colchester. Downloadable from http://www.iser.essex.ac.uk

Burkhauser, R.V., Holden, K.C., and Myers, D.A. (1986), 'Marital disruption and poverty: the role of survey procedures in artificially creating poverty', Demography 23, 62131.

Burkhauser, R.V., Duncan, G.J., Hauser, R. and Berntsen, R. (1990), 'Economic burdens of marital disruptions: a comparison of the United States and the Federal Republic of Germany", Review of Income and Wealth 36, 319-33.

Burkhauser, R.V., Duncan, G.J., Hauser, R. and Berntsen, R. (1991), 'Wife or Frau, women do worse: a comparison of men and women in the United States and Germany after marital dissolution', Demography 28, 353-60.

Burkhauser, R.V., Holtz-Eakin, D., and Rhody, S. (1998), 'Mobility and inequality in the 1980s: a cross-national comparison of the United States and Germany', in Jenkins S.P., Kapteyn A., and van Praag B.M.S. (eds.) The Distribution of Household Welfare and Household Production, Cambridge University Press, Cambridge.

Burkhauser, R.V., Butrica, B.A., Daly, M.C. and Lillard, D. (2000), 'The Cross-national Equivalent File: a product of cross-national research', unpublished paper, Cornell 
University. To appear in: Becker I., Ott N., and Rolf-Engel, G. (eds.), volume in honour of Richard Hauser, Campus-Verlag.

Citro, C.F. and Michael, R.T. (eds.) (1995), Measuring Poverty: A New Approach, National Academy Press, Washington DC.

DiPrete, T.A. and McManus, P.A. (2000), 'Family change, employment transitions, and the welfare state: household income dynamics in the United States and Germany', American Sociological Review 65, 343-70.

Ditch, J., Barnes, H., and Bradshaw, J. (1996) A Synthesis of National Family Policies 1995, University of York for Commission of the European Communities, York.

Duncan, G.J. Gustafsson, B., Hauser, R., Schmauss, G., Messinger, H., Muffels, R., Nolan, B., and Ray, J.-C. (1993), 'Poverty dynamics in eight countries', Journal of Population Economics 6, 215-34.

Ellwood, D. (1998), 'Dynamic policy making: an insider's account of reforming US welfare', in Leisering, L. and Walker, R. (eds.), The Dynamics of Modern Society: Policy, Poverty and Welfare, The Policy Press, Bristol.

Eurostat (1997), 'Income distribution and poverty in EU12 - 1993', Statistics in Focus. Population and Social Conditions 1996-7. Eurostat, Luxembourg.

Eurostat (2000), Eurostat Yearbook. A Statistical Eye on Europe. Data 1988-1998, Eurostat, Luxembourg.

Eurostat Task Force (1998), 'Recommendations on social exclusion and poverty statistics', Document CPS/98/31/2, Eurostat, Luxembourg.

Gottschalk, P., and Danziger, S. (2001), 'Income mobility and exits from poverty by US children', in Bradbury, B., Jenkins S.P. and Micklewright, J. (eds.), The Dynamics of Child Poverty in Industrialised Countries, Cambridge University Press, Cambridge, forthcoming.

Holden, K.C. and Smock, P.J. (1991) 'The economic costs of marital dissolution: why do women bear a disproportionate cost?', Annual Reviews of Sociology 17, 51-78.

Jarvis, S. and Jenkins, S.P. (1997), 'Marital splits and income changes: evidence from the British Household Panel Survey', Population Studies 53, 237-54.

Jenkins, S.P. (2000), 'Modelling household income dynamics', Journal of Population Economics 34, 529-567.

Jenkins, S.P. and Cowell, F.A. (1994), 'Parametric equivalence scales and scale relativities', Economic Journal 104, 891-900. 
Nickell, S. (1997) 'Unemployment and labour market rigidities', Journal of Economic Perspectives, 11, 55-74.

OECD (1999), Benefit Systems and Work Incentives. Country Chapters, http://www.oecd.org/els/spd/index.htm (accessed September 2000).

Piachaud, D. and Sutherland, H. (2000), 'How effective is the British government's attempt to reduce child poverty?', CASE Paper 38, London School of Economics, London. Downloadable from http://sticerd.lse.ac.uk/case/.

Picot, G., Zyblock, M., and Pyper, W. (1999) 'Why do children move into and out of low income: changing labour market conditions or marriage and divorce?', Analytical Studies Branch Research Paper No. 132, Statistics Canada, Ottawa. Downloadable from http://www.statcan.ca.

Preston, I. (1995), 'Sampling distributions for relative poverty statistics'. Applied Statistics 44, 91-9.

Schluter, C. and Trede, M. (1999), 'Local versus global assessments of mobility', Discussion Paper in Statistics and Econometrics No. 4/99, University of Cologne, Cologne.

HM Treasury, (1999), 'Tackling poverty and extending opportunity', The Modernisation of Britain's Tax and Benefit System Paper No. 4, HM Treasury, London.

United Kingdom (1999), Opportunity for All: Tackling Poverty and Social Exclusion, Cm 4445, The Stationery Office, London. Downloadable from http://www.dss.gov.uk. 


\section{Figure 1}

Child poverty rates (\%) in Britain and Western Germany, 1991-8,

by poverty line type

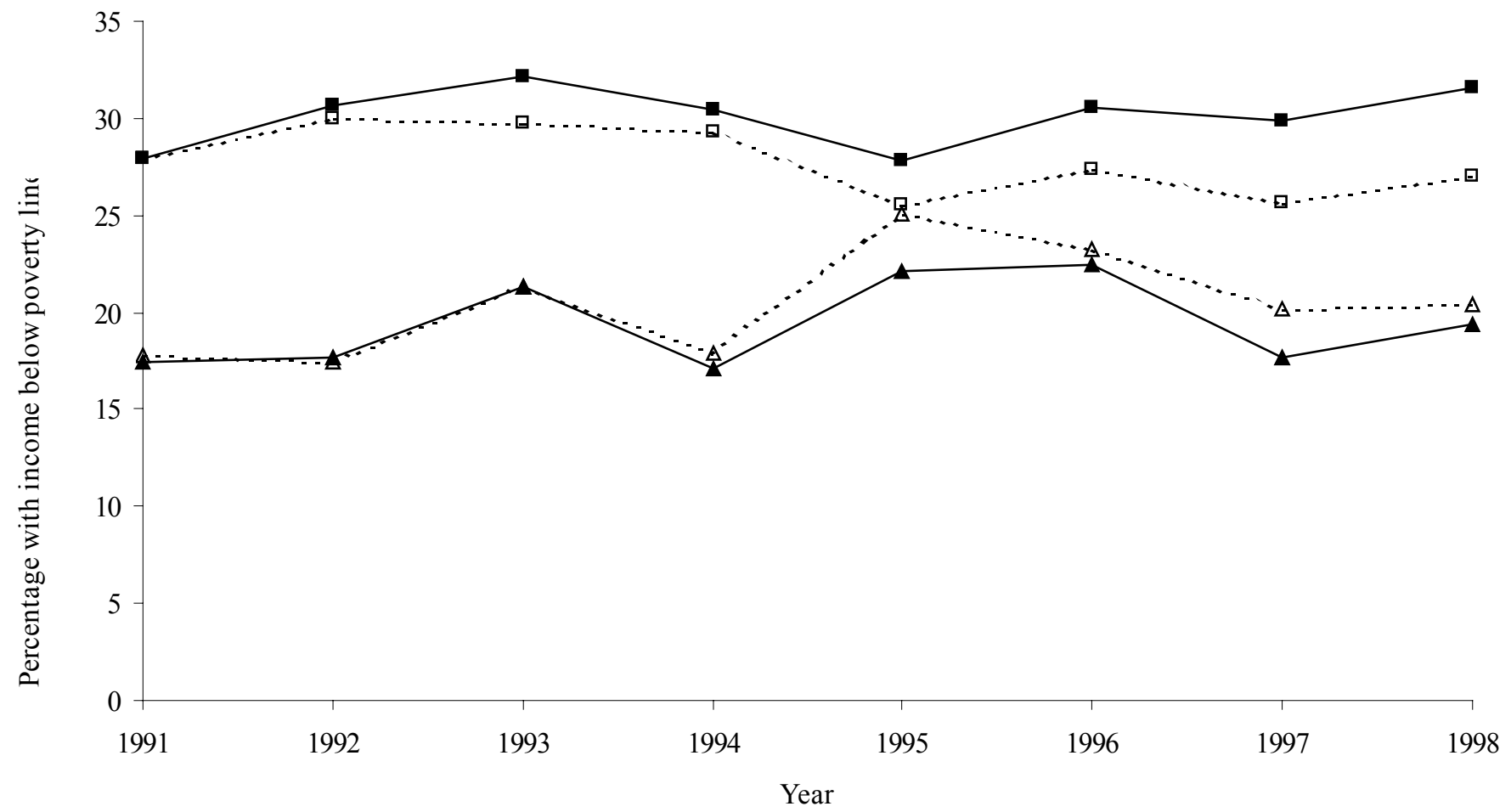

$\longrightarrow$ Britain (relative) $\longrightarrow \longrightarrow$ Western Germany (relative) - - - $\square$ - - Britain (absolute) - - - $\Delta$ - - Western Germany (absolute)

Source: authors' calculations from BHPS and GSOEP data. Definitions explained in Section 3. The relative poverty line is 60 percent of contemporary national median income. The absolute poverty line is 60 percent of 1991 median income in Britain. 
Table 1

Annual poverty rates and poverty exit and entry rates for children (pooled data, 1991-8)

\begin{tabular}{|c|c|c|c|c|c|c|}
\hline \multirow[t]{2}{*}{ Child's household type } & \multicolumn{2}{|c|}{ Poverty rate $(\%)$} & \multicolumn{2}{|c|}{ Exit rate $(\%)$} & \multicolumn{2}{|c|}{ Entry rate $(\%)$} \\
\hline & Britain & $\begin{array}{l}\text { Western } \\
\text { Germany }\end{array}$ & Britain & $\begin{array}{l}\text { Western } \\
\text { Germany }\end{array}$ & Britain & $\begin{array}{l}\text { Western } \\
\text { Germany }\end{array}$ \\
\hline All children & $\begin{array}{l}30.1 \\
(0.5)\end{array}$ & $\begin{array}{l}19.4 \\
(0.6)\end{array}$ & $\begin{array}{l}25.0 \\
(1.0)\end{array}$ & $\begin{array}{l}36.1 \\
(2.1)\end{array}$ & $\begin{array}{l}11.3 \\
(0.5)\end{array}$ & $\begin{array}{c}7.1 \\
(0.5)\end{array}$ \\
\hline Lone parent household & $\begin{array}{l}68.1 \\
(1.3)\end{array}$ & $\begin{array}{l}49.1 \\
(0.3)\end{array}$ & $\begin{array}{l}20.4 \\
(1.5)\end{array}$ & $\begin{array}{l}33.4 \\
(5.1)\end{array}$ & $\begin{array}{l}24.9 \\
(2.4)\end{array}$ & $\begin{array}{l}17.1 \\
(3.5)\end{array}$ \\
\hline Married couple household & $\begin{array}{l}22.4 \\
(0.5)\end{array}$ & $\begin{array}{l}16.3 \\
(0.6)\end{array}$ & $\begin{array}{l}27.3 \\
(1.3)\end{array}$ & $\begin{array}{l}36.2 \\
(2.3)\end{array}$ & $\begin{array}{r}9.9 \\
(2.4)\end{array}$ & $\begin{array}{r}6.4 \\
(0.5)\end{array}$ \\
\hline 'Other' household & $\begin{array}{l}46.4 \\
(2.6)\end{array}$ & $\begin{array}{l}33.3 \\
(3.6)\end{array}$ & $\begin{array}{l}27.1 \\
(4.1)\end{array}$ & $\begin{array}{l}51.2 \\
(7.9)\end{array}$ & $\begin{array}{l}23.1 \\
(3.2)\end{array}$ & $\begin{array}{l}16.7 \\
(5.0)\end{array}$ \\
\hline
\end{tabular}

Standard errors (adjusted for repeated observations per household per year) are shown in parentheses. Transition rates calculated as the number of poverty transitions between years $t-1$ and $t$, divided by the number of children at risk of a transition in year $t-1$ (sample restricted to individuals who are children at years $t-1$ and $t$; child's household type measured at $t-1$ ). Poverty line $=60 \%$ of contemporary national median income. 
Table 2

Poverty exits by poor children in lone parent households

(pooled data, 1991-8)

\begin{tabular}{ccccc}
\hline \hline & Britain & \multicolumn{2}{c}{ Western } \\
& & \multicolumn{2}{c}{ Germany } \\
& $\%$ & (s.e.) & $\%$ & (s.e.) \\
\hline
\end{tabular}

All children at $t-1$ at risk of poverty exit

$\operatorname{pr}(\text { not poor at } t)^{\mathrm{a}}$

$\operatorname{pr}(\text { not poor at } t+1)^{\mathrm{b}}$

$20.4 \quad(1.5) \quad 33.4$

$25.8 \quad(1.9) \quad 43.7$

Household size fell

$\operatorname{pr}($ event $)$

$\operatorname{pr}($ not poor at $t$ event)

$\operatorname{pr}($ not poor at $t+1 \mid$ event $)$

$\begin{array}{rccc}1.3 & (0.4) & 0.0 & (-) \\ 3.1 & (3.1) & - & (-) \\ 17.7 & (12.7) & - & (-)\end{array}$

Left lone parent household

$\operatorname{pr}($ event $)$

$17.0 \quad(1.5) \quad 12.6$

$\operatorname{pr}($ not poor at $t \mid$ event)

46.0

(4.7) $\quad 48.6$

$\operatorname{pr}($ not poor at $t+1 \mid$ event $)$

40.8

(5.2) $\quad 56.6$

Gained full-time worker(s)

$\operatorname{pr}($ event $)$
$\operatorname{pr}($ not poor at $t \mid$ event $)$

$8.9 \quad(1.1) \quad 14.6$

$\begin{array}{lll}74.1 & (5.0) \quad 82.2\end{array}$

$\operatorname{pr}($ not poor at $t+1 \mid$ event)

65.3

(6.5) $\quad 68.1$

Both of above

$\operatorname{pr}($ event $)$

6.0

(1.6) $\quad 5.3$

$\operatorname{pr}($ not poor at $t \mid$ event)

$83.5 \quad(5.0) \quad 91.7$

$\operatorname{pr}($ not poor at $t+1 \mid$ event $)$

$65.3 \quad(6.5) \quad 75.6$

Labour earnings increased by $20 \%$ or more (number of workers unchanged)

$\operatorname{pr}($ event $)$
$\operatorname{pr}($ not poor at $t \mid$ event $)$
$\operatorname{pr}($ not poor at $t+1 \mid$ event $)$

$65.2 \quad(1.9) \quad 50.0$

$11.1 \quad(1.5) \quad 32.3$

$17.3 \quad(2.0) \quad 48.0$

Standard errors (adjusted for repeated observations per household per year) are shown in parentheses. Expressions pr(.) are defined in the main text. Events refer to changes between years $t-1$ and $t$. ${ }^{a}$ : Poverty exit refers to change in poverty status between years $t-1$ and $t$. $^{\text {b: }}$ Poverty exit refers to change in poverty status between years $t-1$ and $t+1$. Sample restricted to individuals who were children at years $t-1$ and $t$, and poor children in lone parent households at year $t-1$. Total (unweighted) number of children at risk of poverty exit $=1668$ (Britain), 394 (Western Germany). Poverty line $=60 \%$ of contemporary national median income. 
Table 3

Poverty exits by poor children in married couple households (pooled data, 1991-8)

\begin{tabular}{ccccc}
\hline \hline & \multicolumn{3}{c}{ Britain } & \multicolumn{2}{c}{ Western Germany } \\
& $\%$ & (s.e.) & $\%$ & (s.e.) \\
\hline
\end{tabular}

All children at $t-1$ at risk of poverty exit

$\begin{array}{llll}\operatorname{pr}(\text { not poor at } t)^{\mathrm{a}} & 27.3 & (1.3) & 36.2 \\ \operatorname{pr}(\text { not poor at } t+1)^{\mathrm{b}} & 35.6 & (1.6) & 42.4\end{array}$

Household size fell (and remain in married couple household)

$\begin{array}{lrcrc}\operatorname{pr}(\text { event }) & 1.7 & (0.4) & 2.2 & (0.5) \\ \operatorname{pr}(\text { not poor at } t \mid \text { event }) & 34.2 & (10.6) & 37.9 & (10.8) \\ \operatorname{pr}(\text { not poor at } t+1 \mid \text { event }) & 75.0 & (8.0) & 55.7 & (13.0)\end{array}$

Gained 1+ worker(s)

pr(event)

$20.1 \quad(1.3) \quad 15.1$

$\operatorname{pr}($ not poor at $t \mid$ event $)$

41.0

(3.4) $\quad 50.0$

$\operatorname{pr}($ not poor at $t+1 \mid$ event $)$

42.5

(3.9) $\quad 62.7$

(6.4)

Gained 1+ full-time worker

$\operatorname{pr}($ event)

$15.4 \quad(1.2) \quad 10.9$

$\operatorname{pr}$ (not poor at $t \mid$ event)

50.0

(4.2) $\quad 56.5$

$\operatorname{pr}($ not poor at $t+1$ event)

51.8

(4.6) $\quad 63.0$

Labour earnings increased by $20 \%$ or more (number of workers unchanged)

$\begin{array}{llll}\operatorname{pr}(\text { event }) & 40.8 & (1.7) & 32.0 \\ \operatorname{pr}(\text { not poor at } t \mid \text { event }) & 28.3 & (2.3) & 62.9 \\ \operatorname{pr}(\text { not poor at } t+1 \mid \text { event }) & 36.2 & (2.9) & 56.8\end{array}$

Standard errors (adjusted for repeated observations per household per year) are shown in parentheses. Expressions pr(.) are defined in the main text. Events refer to changes between years $t-1$ and $t$. $^{\mathrm{a}}$ : Poverty exit refers to change in poverty status between years $t-1$ and $t$. ${ }^{\mathrm{b}}$ : Poverty exit refers to change in poverty status between years $t-1$ and $t+1$. Sample restricted to individuals who were children at years $t-1$ and $t$, and poor children in married couple households at year $t-1$. Total (unweighted) number of poor children at risk of poverty exit $=3,410$ (Britain), 2,464 (Western Germany). Poverty line $=60 \%$ of contemporary national median income. 
Table 4

Poverty entries by non-poor children in married couple households (pooled data, 1991-8)

\begin{tabular}{crrrr}
\hline \hline & \multicolumn{2}{c}{ Britain } & \multicolumn{2}{c}{ Western Germany } \\
& $\%$ & (s.e.) & $\%$ & (s.e.) \\
\hline $\begin{array}{c}\text { All children at } t-1 \text { at risk of poverty entry } \\
\operatorname{pr}(\text { poor at } t)^{\text {a }}\end{array}$ & 9.9 & $(0.5)$ & 6.4 & $(0.5)$ \\
$\operatorname{pr}($ poor at $t+1){ }^{\mathrm{b}}$ & 11.7 & $(0.5)$ & 6.3 & $(0.5)$
\end{tabular}

Household size rose (but remained in married couple household)

$\begin{array}{lrrrr}\operatorname{pr}(\text { event }) & 6.0 & (0.3) & 4.8 & (0.3) \\ \operatorname{pr}(\text { poor at } t \text { event }) & 18.0 & (2.4) & 9.0 & (1.6) \\ \operatorname{pr}(\text { poor at } t+1 \mid \text { event }) & 20.2 & (2.6) & 11.0 & (2.3)\end{array}$

Joined lone parent household

$\begin{array}{lrrrr}\operatorname{pr}(\text { event }) & 3.2 & (0.3) & 1.6 & (0.2) \\ \operatorname{pr}(\text { poor at } t \text { |event) } & 61.8 & (4.1) & 58.9 & (7.2) \\ \operatorname{pr}(\text { poor at } t+1 \mid \text { event) } & 48.4 & (4.7) & 23.6 & (5.9) \\ & & & & \\ \text { worker(s) } & & & & \\ \operatorname{pr}(\text { event }) & 18.0 & (0.6) & 8.7 & (0.5) \\ \operatorname{pr}(\text { poor at } t \mid \text { event }) & 23.0 & (1.6) & 20.0 & (2.5) \\ \operatorname{pr}(\text { poor at } t+1 \mid \text { event }) & 21.9 & (1.7) & 12.7 & (1.8)\end{array}$

Both of above

$\begin{array}{lrrrr}\operatorname{pr}(\text { event }) & 1.9 & (0.2) & 1.4 & (0.2) \\ \operatorname{pr}(\text { poor at } t \mid \text { event }) & 64.7 & (5.0) & 65.1 & (6.9) \\ \operatorname{pr}(\text { poor at } t+1 \mid \text { event }) & 49.4 & (5.7) & 23.8 & (6.3)\end{array}$

Lost 1+ full-time worker(s)

$\begin{array}{llrrr}\operatorname{pr}(\text { event }) & 17.0 & (0.6) & 8.3 & (0.5) \\ \operatorname{pr}(\text { poor at } t \mid \text { event }) & 22.0 & (1.6) & 21.5 & (2.6) \\ \operatorname{pr}(\text { poor at } t+1 \mid \text { event }) & 20.5 & (1.8) & 12.8 & (1.5)\end{array}$

Labour earnings fell by $20 \%$ or more

(number of workers unchanged)

$\begin{array}{lrrrr}\operatorname{pr}(\text { event }) & 8.4 & (0.4) & 8.0 & (0.5) \\ \operatorname{pr}(\text { poor at } t \mid \text { event }) & 27.7 & (2.5) & 19.3 & (2.6) \\ \operatorname{pr}(\text { poor at } t+1 \mid \text { event }) & 27.1 & (2.7) & 12.7 & (1.8)\end{array}$

Children newborn at $t$

\begin{tabular}{|c|c|c|c|c|}
\hline $\operatorname{pr}$ (household with newborn) ${ }^{\mathrm{c}}$ & 4.3 & $(0.1)$ & 1.0 & $(0.1)$ \\
\hline $\operatorname{pr}(\text { poor at } t \mid \text { newborn child })^{d}$ & 27.2 & $(1.5)$ & 25.9 & $(5.9$ \\
\hline
\end{tabular}


Standard errors (adjusted for repeated observations per household per year) are shown in parentheses. Expressions pr(.) are defined in the main text. Events refer to changes between years $t-1$ and $t$. ${ }^{\text {a}}$ : Poverty exit refers to change in poverty status between years $t-1$ and $t .^{\text {b}}$ : Poverty exit refers to change in poverty status between years $t-1$ and $t+1$. Sample restricted to individuals who were children at years $t-1$ and $t$ and non-poor children in married couple households at year $t-1$. Total (unweighted) number of non-poor children at $t-1$ at risk of poverty entry $=11,630$ (Britain), 12,682 (Western Germany). ${ }^{\mathrm{c}}$ : Proportion of married couple households at $t$ containing a newborn child. (The German figure is an under-estimate - see text.) ${ }^{\mathrm{d}}$ : Proportion of newborn children at $t$ who were poor at $t$. Poverty line $=60 \%$ of contemporary national median income. 


\section{Appendix A. Sensitivity analysis: how pr(poverty transition|event) varies with changes to the equivalence scale}

Table A2

Poverty exits by poor children in lone parent households (pooled data, 1991-8), by equivalence scale

$\operatorname{pr}($ not poor at $t \mid$ event $)$, by event

\begin{tabular}{|c|c|}
\hline Britain & Western Germany \\
\hline
\end{tabular}

All children at $t-1$ at risk of poverty exit

$\begin{array}{llll}\alpha=0.7, \beta=0.75 & 25.8 & (1.9) & 43.7 \\ \alpha=0.7, \beta=0.5 & 20.2 & (1.5) & 29.2 \\ \alpha=0.5, \beta=0.75 & 25.4 & (1.7) & 40.2 \\ \alpha=0.5, \beta=0.5 & 24.0\end{array}$

$\alpha=0.5, \beta=0.5$

3.1

$(3.1)$

$(-)$

$\alpha=0.7, \beta=0.75$

6.5

$\alpha=0.5, \beta=0.75$

3.4

(4.8)

$\alpha=0.5, \beta=0.5$

3.4

Left lone parent household

$$
\begin{aligned}
& \alpha=0.7, \beta=0.75 \\
& \alpha=0.7, \beta=0.5 \\
& \alpha=0.5, \beta=0.75 \\
& \alpha=0.5, \beta=0.5
\end{aligned}
$$

46.0

(4.7) $\quad 48.6$

55.3

(4.6) $\quad 48.4$

52.5

(5.0) $\quad 50.3$

55.7

(4.7)

51.2

Gained full-time worker(s)

$$
\begin{aligned}
& \alpha=0.7, \beta=0.75 \\
& \alpha=0.7, \beta=0.5 \\
& \alpha=0.5, \beta=0.75 \\
& \alpha=0.5, \beta=0.5
\end{aligned}
$$

75.5

81.9

77.3

(5.0) $\quad 87.4$

76.2

(4.7)

83.7

Both of above

$$
\begin{aligned}
& \alpha=0.7, \beta=0.75 \\
& \alpha=0.7, \beta=0.5 \\
& \alpha=0.5, \beta=0.75 \\
& \alpha=0.5, \beta=0.5
\end{aligned}
$$

86.8

91.7

86.6

(4.4) $\quad 100.0$

87.2

(4.0) $\quad 100.0$

Labour earnings increased by $20 \%$ or more (number of workers unchanged)

$$
\begin{aligned}
& \alpha=0.7, \beta=0.75 \\
& \alpha=0.7, \beta=0.5 \\
& \alpha=0.5, \beta=0.75 \\
& \alpha=0.5, \beta=0.5
\end{aligned}
$$

$\begin{array}{lll}11.1 & (1.5) & 32.3 \\ 10.2 & (1.4) & 31.1 \\ 14.5 & (1.8) & 41.9 \\ 15.0 & (1.9) & 32.7\end{array}$

Standard errors (adjusted for repeated observations per household per year) are shown in parentheses. Events and poverty exits refer to changes between years $t-1$ and $t$; pr(event) estimates as in Table 2. Equivalence scale $=[$ (number of adults $)+\alpha^{*}($ number of children $\left.)\right]^{\beta}$. Poverty line $=60 \%$ of contemporary national median income. 
Table A3

Poverty exits by poor children in married couple households (pooled data, 1991-8), by equivalence scale

pr(not poor at $t \mid$ event), by event Britain Western Germany

$\% \quad$ (s.e.)
$\%$ (s.e.)

All children at $t-1$ at risk of poverty exit

$$
\begin{aligned}
& \alpha=0.7, \beta=0.75 \\
& \alpha=0.7, \beta=0.5 \\
& \alpha=0.5, \beta=0.75 \\
& \alpha=0.5, \beta=0.5
\end{aligned}
$$

$$
\text { (1.3) }
$$

36.2

35.6

Household size fell (and remain in married couple household)

$$
\begin{aligned}
& \alpha=0.7, \beta=0.75 \\
& \alpha=0.7, \beta=0.5 \\
& \alpha=0.5, \beta=0.75 \\
& \alpha=0.5, \beta=0.5
\end{aligned}
$$

$\begin{array}{lll}34.2 & (10.6) & 37.9 \\ 34.8 & (11.2) & 20.4 \\ 34.2 & (10.6) & 37.8 \\ 31.3 & (10.4) & 27.5\end{array}$

Gained 1+ worker(s)

$$
\begin{aligned}
& \alpha=0.7, \beta=0.75 \\
& \alpha=0.7, \beta=0.5 \\
& \alpha=0.5, \beta=0.75 \\
& \alpha=0.5, \beta=0.5
\end{aligned}
$$$$
41.0
$$$$
46.4
$$

50.0

54.2

48.0

48.6

Gained 1+ full-time worker

$$
\begin{aligned}
& \alpha=0.7, \beta=0.75 \\
& \alpha=0.7, \beta=0.5 \\
& \alpha=0.5, \beta=0.75 \\
& \alpha=0.5, \beta=0.5
\end{aligned}
$$

\begin{tabular}{|c|c|c|c|c|}
\hline$\alpha=0.7, \beta=0.75$ & 28.3 & $(2.3)$ & 62.9 & $(4.2)$ \\
\hline$\alpha=0.7, \beta=0.5$ & 28.0 & $(2.4)$ & 60.0 & (4.4) \\
\hline$\alpha=0.5, \beta=0.75$ & 27.9 & $(2.4)$ & 59.0 & $(4.2)$ \\
\hline$\alpha=0.5, \beta=0.5$ & 32.5 & $(2.3)$ & 59.3 & (4.6) \\
\hline
\end{tabular}

60.5

56.5

(4.5) $\quad 75.5$

Labour earnings increased by $20 \%$ or more (number of workers unchanged)

Standard errors (adjusted for repeated observations per household per year) are shown in parentheses. Events and poverty exits refer to changes between years $t-1$ and $t$; pr(event) estimates as in Table 3. Equivalence scale $=[$ (number of adults $)+\alpha^{*}($ number of children $\left.)\right]^{\beta}$. :Poverty line $=$ $60 \%$ of contemporary national median income. 
Table A4

Poverty entries by non-poor children in married couple households (pooled data, 1991-8), by equivalence scale

\begin{tabular}{crrrr}
\hline \hline pr(poor at $t \mid$ event), by event & \multicolumn{3}{c}{ Britain } & \multicolumn{2}{c}{ Western Germany } \\
& $\%$ & (s.e.) & $\%$ & (s.e.) \\
\hline All children at $t-1$ at risk of poverty entry & & & & \\
$\alpha=0.7, \beta=0.75$ & 11.7 & $(0.5)$ & 6.3 & $(0.5)$ \\
$\alpha=0.7, \beta=0.5$ & 9.5 & $(0.4)$ & 4.8 & $(0.4)$ \\
$\alpha=0.5, \beta=0.75$ & 9.6 & $(0.4)$ & 5.3 & $(0.4)$ \\
$\alpha=0.5, \beta=0.5$ & 8.9 & $(0.4)$ & 4.4 & $(0.4)$
\end{tabular}

Household size rose (but remained in married couple household)

$$
\begin{aligned}
& \alpha=0.7, \beta=0.75 \\
& \alpha=0.7, \beta=0.5 \\
& \alpha=0.5, \beta=0.75 \\
& \alpha=0.5, \beta=0.5
\end{aligned}
$$

18.0

15.9

17.6

12.3

(2.4)

(2.4)

9.0

6.9

5.9

5.9

Joined lone parent household

$$
\begin{aligned}
& \alpha=0.7, \beta=0.75 \\
& \alpha=0.7, \beta=0.5 \\
& \alpha=0.5, \beta=0.75 \\
& \alpha=0.5, \beta=0.5
\end{aligned}
$$

61.8

67.7

(4.1) $\quad 58.9$

58.9

(3.9)

60.7

64.0

(4.0)

56.5

(3.9) $\quad 57.5$

Lost $1+$ worker(s)

$$
\begin{aligned}
& \alpha=0.7, \beta=0.75 \\
& \alpha=0.7, \beta=0.5 \\
& \alpha=0.5, \beta=0.75 \\
& \alpha=0.5, \beta=0.5
\end{aligned}
$$

23.0

(1.6) 20.0

22.9

22.0

(1.6) $\quad 18.1$

22.0

(1.6)

17.6

(1.5) $\quad 17.9$

Both of above

$$
\begin{aligned}
& \alpha=0.7, \beta=0.75 \\
& \alpha=0.7, \beta=0.5 \\
& \alpha=0.5, \beta=0.75 \\
& \alpha=0.5, \beta=0.5
\end{aligned}
$$

65.1

71.8

(4.7)

66.9

60.1

(5.1)

61.9

66.8

(4.8)

65.6

Lost 1+ full-time worker(s)

$$
\begin{aligned}
& \alpha=0.7, \beta=0.75 \\
& \alpha=0.7, \beta=0.5 \\
& \alpha=0.5, \beta=0.75 \\
& \alpha=0.5, \beta=0.5
\end{aligned}
$$

22.0

(1.6) $\quad 21.5$

22.3

(1.6) $\quad 20.5$

20.9

(1.6) 20.3

20.5

(1.6) $\quad 20.7$

Labour earnings fell by $20 \%$ or more (number of workers unchanged)

$$
\begin{aligned}
& \alpha=0.7, \beta=0.75 \\
& \alpha=0.7, \beta=0.5 \\
& \alpha=0.5, \beta=0.75 \\
& \alpha=0.5, \beta=0.5
\end{aligned}
$$

Children newborn at $t$

$$
\begin{aligned}
& \alpha=0.7, \beta=0.75 \\
& \alpha=0.7, \beta=0.5 \\
& \alpha=0.5, \beta=0.75 \\
& \alpha=0.5, \beta=0.5
\end{aligned}
$$


Standard errors (adjusted for repeated observations per household per year) are shown in parentheses. Events and poverty entries refer to changes between years $t-1$ and $t$; $\operatorname{pr}$ (event) estimates as in Table 4 . Equivalence scale $=\left[(\text { number of adults })+\alpha^{*}(\text { number of children })\right]^{\beta}$. Poverty line $=60 \%$ of contemporary national median income. 


\section{Appendix B. Sensitivity analysis: how pr(poverty transition|event) varies with alternative definitions of the poverty line and of a poverty transition}

Table B2

Poverty exits by poor children in lone parent households (pooled data, 1991-8), by poverty line type

pr(not poor at $t \mid$ event $)$, by event

All children at $t-1$ at risk of poverty exit Relative poverty line ${ }^{\mathrm{a}}$

Relative line, transitions adjusted ${ }^{\mathrm{b}}$

Absolute poverty line ${ }^{\mathrm{c}}$

Poorest quintile line ${ }^{\mathrm{d}}$

Household size fell

Relative poverty line ${ }^{\mathrm{a}}$

Relative line, transitions adjusted ${ }^{\mathrm{b}}$

Absolute poverty line ${ }^{\mathrm{c}}$

Poorest quintile line ${ }^{\mathrm{d}}$

Left lone parent household

Relative poverty line

Relative line, transitions adjusted ${ }^{\mathrm{b}}$

Absolute poverty line ${ }^{\mathrm{c}}$

Poorest quintile line ${ }^{\mathrm{d}}$

Gained full-time worker(s)

Relative poverty line ${ }^{\mathrm{a}}$

Relative line, transitions adjusted ${ }^{b}$

Absolute poverty line ${ }^{c}$

Poorest quintile line ${ }^{\mathrm{d}}$

Both of above

Relative poverty line ${ }^{\mathrm{a}}$

Relative line, transitions adjusted ${ }^{\mathrm{b}}$

Absolute poverty line ${ }^{\mathrm{c}}$

Poorest quintile line ${ }^{\mathrm{d}}$

Labour earnings increased by $20 \%$ or more

(number of workers unchanged)

Relative poverty line ${ }^{a}$

Relative line, transitions adjusted ${ }^{\mathrm{b}}$

Absolute poverty line ${ }^{\mathrm{c}}$

Poorest quintile line ${ }^{\mathrm{d}}$

Britain

$\% \quad$ (s.e.)

Western Germany

$\% \quad$ (s.e.)

$\begin{array}{lll}25.8 & (1.9) & 43.7 \\ 15.4 & (1.3) & 25.7 \\ 24.0 & (1.6) & 29.8 \\ 20.3 & (1.5) & 25.4\end{array}$

$\begin{array}{llll}3.1 & (3.1) & - & (-) \\ 3.1 & (3.1) & - & (-) \\ 3.1 & (3.1) & - & (-) \\ 3.1 & (3.1) & - & (-)\end{array}$

46.0

(4.7) $\quad 48.6$

40.5

(4.6)

41.2

51.9

(4.9)

47.2

48.4

(4.8)

36.4

74.1

(5.0)

82.2

68.0

(5.4)

71.3

79.8

(4.6)

82.2

74.6

(5.0)

70.9

83.5

(5.0)

91.7

77.6

(5.7)

79.1

(10.9)

90.7

(3.7)

91.7

84.3

(4.7)

73.9

(10.8)

$\begin{array}{rll}11.1 & (1.5) & 32.3 \\ 7.6 & (1.3) & 27.5 \\ 13.2 & (1.7) & 31.1 \\ 10.7 & (1.5) & 26.8\end{array}$

Standard errors (adjusted for repeated observations per household per year) are shown in parentheses. Events and poverty exits refer to changes between years $t-1$ and $t$; $\operatorname{pr}($ event) estimates as in Table 2 . $^{\text {a }}$ : Poverty line $=60 \%$ of contemporary national median income (as in Table 2). ${ }^{\text {b }}$ As (a), except poverty exit requires income to rise at least 10 percent above the poverty line. ${ }^{\mathrm{c}}$ : Poverty line $=60 \%$ of 1991 British median income. ${ }^{\mathrm{d}}$ : Poverty line $=$ twentieth percentile of contemporary national income distribution for all persons. 
Table B3

Poverty exits by poor children in married couple households (pooled data, 1991-8), by poverty line type

pr(not poor at $t$ event), by event Britain Western Germany

$\% \quad$ (s.e.)
$\% \quad$ (s.e.)

All children at $t-1$ at risk of poverty exit Relative poverty line ${ }^{\mathrm{a}}$ Relative line, transitions adjusted ${ }^{\mathrm{b}}$ Absolute poverty line ${ }^{\mathrm{c}}$ Poorest quintile line ${ }^{\mathrm{d}}$

$\begin{array}{lll}27.3 & (1.3) & 36.2 \\ 19.9 & (1.2) & 22.9 \\ 30.2 & (1.4) & 35.9 \\ 28.1 & (1.4) & 29.0\end{array}$

Household size fell (and remain in married couple household)

Relative poverty line

$\begin{array}{llll}34.2 & (10.6) & 37.9 & (10.8) \\ 32.7 & (10.6) & 26.1 & (9.7) \\ 40.6 & (10.8) & 36.5 & (10.3) \\ 35.5 & (10.4) & 36.2 & (8.4)\end{array}$

Absolute poverty line

Poorest quintile line

35.5

41.0

(3.4) $\quad 50.0$

Relative poverty line

Relative line, transitions adjusted

31.2

(10.6)

36.0

Absolute poverty line

45.0

(10.8)

53.5

Poorest quintile line

42.0

(10.4)

41.4

Gained 1+ full-time worker

Relative poverty line

50.0

56.5

Relative line, transitions adjusted

39.8

(4.0) $\quad 44.9$

Absolute poverty line

53.8

(4.3) $\quad 56.2$

Poorest quintile line

51.1

55.5

(6.6)

Labour earnings increased by $20 \%$ or more (number of workers unchanged)

Relative poverty line

28.3

(2.3)

62.9

Relative line, transitions adjusted

Absolute poverty line

Poorest quintile line

28.8

Standard errors (adjusted for repeated observations per household per year) are shown in parentheses. Events and poverty exits refer to changes between years $t-1$ and $t$; pr(event) estimates as in Table 3 . $^{\mathrm{a}}$ : Poverty line $=60 \%$ of contemporary national median income (as in Table 3 ). ${ }^{\mathrm{b}}$ : As (a), except poverty exit requires income to rise at least 10 percent above the poverty line. ${ }^{c}$ : Poverty line $=60 \%$ of 1991 British median income. ${ }^{\mathrm{d}}:$ Poverty line $=$ twentieth percentile of contemporary national income distribution for all persons. 
Table B4

Poverty entries by non-poor children in married couple households (pooled data, 1991-8), by poverty line type

\begin{tabular}{crrrr}
\hline \hline pr(poor at $t \mid$ event), by event & \multicolumn{3}{c}{ Britain } & \multicolumn{2}{c}{ Western Germany } \\
& $\%$ & (s.e.) & $\%$ & (s.e.) \\
\hline All children at $t-1$ at risk of poverty entry $_{\text {Relative poverty line }}^{\mathrm{a}}$ & & & & \\
Relative line, transitions adjusted $^{\mathrm{b}}$ & 11.7 & $(0.5)$ & 6.3 & $(0.5)$ \\
Absolute poverty line $^{\mathrm{c}}$ & 7.1 & $(0.4)$ & 3.9 & $(0.4)$ \\
Poorest quintile line $^{\mathrm{d}}$ & 9.0 & $(0.4)$ & 7.0 & $(0.5)$ \\
& 9.9 & $(0.5)$ & 8.4 & $(0.6)$
\end{tabular}

Household size rose (but remained in married couple household)

Relative poverty line ${ }^{\mathrm{a}}$

18.0

$(2.4)$

9.0

(1.6)

Relative line, transitions adjusted ${ }^{\mathrm{b}}$

14.0

(2.4)

4.6

(1.2)

Absolute poverty line ${ }^{c}$

Poorest quintile line ${ }^{\mathrm{d}}$

17.9

(2.4) $\quad 9.7$

18.2

(2.4)

15.3

Joined lone parent household

Relative poverty line ${ }^{a}$

Relative line, transitions adjusted ${ }^{b}$

61.8

(4.1) $\quad 58.9$

Absolute poverty line

Poorest quintile line ${ }^{d}$

55.5

59.0

(4.1)

54.4

(7.4)

62.5

(4.0)

60.9

(7.2)

(4.1) 59.1

Lost 1+ worker(s)

Relative poverty line ${ }^{\mathrm{a}}$

Relative line, transitions adjusted ${ }^{b}$

23.0

(1.6) $\quad 20.0$

18.3

(1.5)

15.9

Absolute poverty line

21.5

(1.5) 20.3

Poorest quintile line ${ }^{d}$

23.0

(1.6)

22.1

Both of above

Relative poverty line ${ }^{a}$

Relative line, transitions adjusted ${ }^{b}$

64.7

$(5.0)$

65.1

(6.9)

59.1

(5.2)

60.0

Absolute poverty line ${ }^{c}$

62.7

(5.1) $\quad 67.0$

Poorest quintile line ${ }^{\mathrm{d}}$

65.8

(5.0)

66.0

Lost 1+ full-time worker(s)

Relative poverty line ${ }^{a}$

Relative line, transitions adjusted ${ }^{b}$

22.0

(1.6) 21.5

17.9

(1.5) $\quad 18.0$

Absolute poverty line ${ }^{c}$

Poorest quintile line ${ }^{\mathrm{d}}$

20.4

(1.6) 22.5

(1.6)

23.3

Labour earnings fell by $20 \%$ or more (number of workers unchanged)

Relative poverty line ${ }^{\mathrm{a}}$

Relative line, transitions adjusted ${ }^{\mathrm{b}}$

27.7

20.0

(2.5)

19.3

(2.6)

25.2

(2.3)

11.1

(1.7)

Absolute poverty line

(2.4)

21.1

Poorest quintile line ${ }^{d}$

28.0

(2.5)

(2.7)

(2.9)

Children newborn at $t$

Relative poverty line ${ }^{\mathrm{a}} \quad 27.2$

Relative line, transitions adjusted ${ }^{b}$ 
Standard errors (adjusted for repeated observations per household per year) are shown in parentheses. Events and poverty entries refer to changes between years $t-1$ and $t$; $\operatorname{pr}$ (event) estimates as in Table $4{ }^{\text {a }}{ }^{\circ}$ : Poverty line $=60 \%$ of contemporary national median income (as in Table 4 ). ${ }^{b}$ : As (a), except poverty entry requires income to fall at least 10 percent below the poverty line. ${ }^{c}$ : Poverty line $=60 \%$ of 1991 British median income. ${ }^{\mathrm{d}}$ : Poverty line $=$ twentieth percentile of contemporary national income distribution for all persons. 